\title{
artículos
}

\section{Entre la narración y el símbolo. Iconografía del Ecce Homo en la escultura barroca granadina}

Juan Jesús López-Guadalupe Muñoz

Universidad de Granada

RESUMEN

El Ecce-Homo es una de las más felices creaciones de la iconografía cristiana. El tema constituye un trasunto del "Varón de Dolores" profetizado por Isaías, al evocar el momento de la presentación de Jesucristo al pueblo de Jerusalén por parte de Poncio Pilatos, coronado de espinas, revestido de una clámide púrpura y un cetro de caña entre las manos. A partir del Renacimiento, la visión hedonista del cuerpo de Cristo, propiciada por la interpretación de un desnudo de corte clasicista, se aúna con los valores dramáticos y persuasivos que irán abriéndose camino, decididamente, en las interpretaciones barrocas del asunto. El presente trabajo aborda dichas cuestiones, conectándolas con la problemática particular suscitada desde el ámbito de la escultura granadina de la Edad Moderna, con especial incidencia en los matices conceptuales que diferencian la imagen de devoción, que canaliza la experiencia y la contemplación mística en el ámbito privado, de los valores teatrales inherentes a la función procesional.

PALABRAS CLAVE: Iconografía Cristiana/ Escultura/ Renacimiento/ Barroco.

Between Narration and Symbol. Iconography of "Ecce-Homo" into Baroque Sculpture in Granada.

ABSTRACT

"Ecce-Homo" is one of the most conspicuous themes of Christian Art. Its iconography is considered a faithful image of "Man of Sorrows" descripted by Isaiah, reminding when Jesuschrist was shown to people of Jerusalem by Pontius Pilatus, with a crown of thorns on his head, a purple robe and carrying a reed as scepter. Since Renaissance, the vision of Christ's body was signed by Classicism joining to persuasive and dramatic effects furnished by Baroque. This article studies these aspects and their connections with sculptural versions of "Ecce-Homo" made in Granada between XVI-XVIII centuries, appointing to their mystic, devotional and processional implications.

KEY WORDS: Christian Iconography/ Sculpture/ Renaissance/ Baroque

El gran desarrollo de la imaginería de Pasión en el Barroco español deja en la escuela granadina la peculiaridad iconográfica de una especial abundancia en el tratamiento del tema del Ecce Homo, sólo superado por el episodio central del arte cristiano, el Cristo crucificado. Se ha interpretado la alta significación de ese tipo iconográfico en Granada como una manifestación eminente de los rasgos singulares de esta escuela. Sin embargo, dentro de una especial valoración del asunto durante el Barroco, conviene analizar su especial frecuencia tanto a través de sus peculiaridades iconográficas, como de los valores subyacentes, plasmándose en capitales realizaciones que aquí se intentarán ponderar adecuadamente, en especial las imágenes de carácter procesional, a las que la crítica ha prestado poca atención en el análisis de la escultura granadina ${ }^{1}$.

* LÓPEZ-GUADALUPE MUÑOZ, Juan Jesús: "Entre la narración y el símbolo. Iconografía del Ecce Homo en la escultura barroca granadina", en Boletín de Arte, $n^{\circ} 29$, Departamento de Historia del Arte, Universidad de Málaga, 2008, págs. 85-111. 


\section{1: artículos Juan Jesús López-Guadalupe Muñoz}

\section{iconografia del ECce Homo barroco. Definición y Contenidos.}

El Ecce Homo constituye un tema iconográfico paradigmático en la expresión de los valores de la Contrarreforma y bien considerado desde antiguo por la sensibilidad española, querenciosa de versiones directas y concretas. Ya la piedad medieval había subrayado el dolor físico y moral de Cristo en la soledad del ultraje, preparando para el tipo iconográfico su definitiva emancipación del hecho narrativo.

En efecto, el Ecce Homo corresponde en el relato joánico (19, 1-5) a la Ostentatio Christi o presentación de Cristo al pueblo por Pilatos. Sin embargo, en Granada - como en otros lugares - desde temprana fecha se abstrae y emancipa del concreto episodio evangélico para individualizar la figura de Cristo, segregándolo del resto de los personajes que conforman su contexto narrativo. Son escasas las pinturas granadinas que representan el episodio con todos sus actores y nulas las esculturas, derivando hacia la singularización de un tipo que constituye, por tanto, una representación mística, no histórica, para ponerse al servicio de una reflexión teológica y moral más profunda, no meramente narrativa.

Esto genera cierta imprecisión iconográfica en confusión de tipos y escenas. De este modo, la genérica nomenclatura del Ecce Homo admite también la imagen aislada de Cristo durante la coronación de espinas, el episodio más cercano en el relato evangélico y que comporta iguales atributos, con la única distinción de la posición sedente o en pie de Cristo, lo que nos permite incluirla en este estudio. Igualmente se identifica con el Cristo de la Humildad y Paciencia o Cristo pensativo sentado en una peña, esperando la crucifixión, tipo de gran éxito devocional por su impacto emotivo y muy difundido a partir de las estampas de Durero, o también con el Cristo Varón de Dolores, mostrando sus llagas, tipo nórdico medieval procedente de la Misa de San Gregorio, de marcado carácter simbólico. A ninguno de estos dos nos remitiremos, si bien en el último, el Varón de Dolores, con significado sacramental, como de hostia viviente, puede encontrarse un remoto precedente del Ecce Homo de busto, tan frecuente en la escultura granadina, que tiene en él una de sus prototípicas creaciones ${ }^{2}$.

\footnotetext{
1 Ya he realizado una primera aproximación a estos asuntos en la ponencia titulada "El Ecce Homo en la escultura granadina. Imagen de devoción, imagen de procesión", defendida en el III Congreso Nacional de Cofradías de Semana Santa (Córdoba, 1997) y publicada en sus actas. Ahora se amplían los datos y comentarios, para precisar más el tema, aportando nuevas atribuciones también. Esta revisión tiene lugar dentro de los trabajos realizados en el marco del proyecto de investigación "La difusión del naturalismo en la escultura andaluza e hispanoamericana. Talleres, fuentes, mentalidades e iconografía", financiado por la Dirección General de Investigación del Ministerio de Educación y Ciencia (HUM2006-11294/ARTE).

2 Sobre las alternativas iconográficas de esta representación, consúltense RÉAU, L.: Iconographie de l'art chrétien. París, P.U.F., 1956, II.2, págs. 42-43; ORUETA Y DUARTE, R. de: La expresión de dolor en la escultura castellana. Madrid, Real Academia de Bellas Artes de San Fernando, 1924, pág. 19; VETTER, E. M.: "Iconografía del 'Varón de Dolores'. Su significado y origen", Archivo Español de Arte, 36, Madrid, 1963, págs. 197-231; HERNÁNDEZ PERERA, J.: "Iconografía española. El Cristo de los Dolores", Archivo Español
} 
Será, pues, a las dos primeras escenas reseñadas, la Coronación de espinas y la Presentación al pueblo, a las que con mayor propiedad se adscriba la figura individualizada del Ecce Homo, con independencia del episodio concreto al que pertenezca o incluso sin pertenecer de modo efectivo a ninguno, como ocurre en el caso de las imágenes de busto, a las que en algún caso cabría encuadrar incluso fuera de los dos episodios enunciados, para trasladarlas a una hipotética oración previa a la crucifixión en el Calvario.

Queda ya clara, desde luego, una característica formal del Ecce Homo granadino, su carácter aislado e individualizado, aunque no por ello ayuno de valores procesionales (si bien en ejemplos puntuales), pero ajeno, por tanto, a la composición con otras figuras, al "paso de misterio", lo que obliga al escultor a la economía de medios narrativos y a la optimización de recursos expresivos, ofreciendo siempre una versión espiritualizada y simbólica. De ahí el paralelismo en clave emblemática que se ha querido ver con el Varón de Dolores centroeuropeo, singularmente en el caso de las efigies de busto.

El carácter idóneo de este tema como mecanismo de incentivo de la devoción se demuestra, en primer lugar, en el énfasis que esta representación pone en la humanidad doliente de Cristo. Esta atención a la naturaleza humana de Cristo posee claros antecedentes bajomedievales y en nuestro país brota con espontaneidad por doquier, especialmente desde que el apego a la representación naturalista se vuelve definitivo en el Seiscientos. Este carácter no requiere mayor alegoría, respetando su veracidad histórica, para emocionar y mover a devoción, recreando las prefiguraciones bíblicas, especialmente aquella imponente de Isaías: "despreciado, desecho de los hombres, varón de dolores, conocedor de todos los quebrantos, ante quien se vuelve el rostro, menospreciado, estimado en nada" $(53,3)$, punto de partida de muchos devocionarios de la época.

Su potencial narrativo y emocionante fue recogido a la perfección por nuestros místicos. Así lo meditaba Fray Luis de Granada: "Mira pues agora, ánima mía, quién sea este Señor, que teniendo imagen de Rey, está como siervo despreciado, lleno de confusión. Está coronado con corona; mas esa corona traspasa su cabeza con agudas espinas. Está vestido de púrpura real; mas en ella no es honrado, sino despreciado. Tiene por cetro real una caña en la mano; mas con ella le hieren en la cabeza. Adóranlo hincadas las rodillas, y llámanlo rey; mas escupen su rostro, y danle de bofetadas y pescozones"3.

A la hora de considerar estas interpretaciones de la humanidad doliente de Cristo, debe advertirse el rotundo carácter inmanente que poseen. La imagen procede de la experiencia religiosa de un artista y de todo un pueblo, de la vida interior

de Arte, 27, Madrid, 1954, págs. 47-62; VARELA, F. M.: "Sur les origines iconographiques du Christ de l'Humilité et de la Patience, une dévotion propagée par les jésuites en Amérique espagnole", Gazette des Beaux Arts, 86, París, 1972, pág. 207.

3 "Meditaciones muy devotas", capítulo XVI, en Obras del V. P. M. Fray Luis de Granada, t. II. Madrid, Atlas, 1945, pág. 536. 


\section{Q: artículos Juan Jesús López-Guadalupe Muñoz}

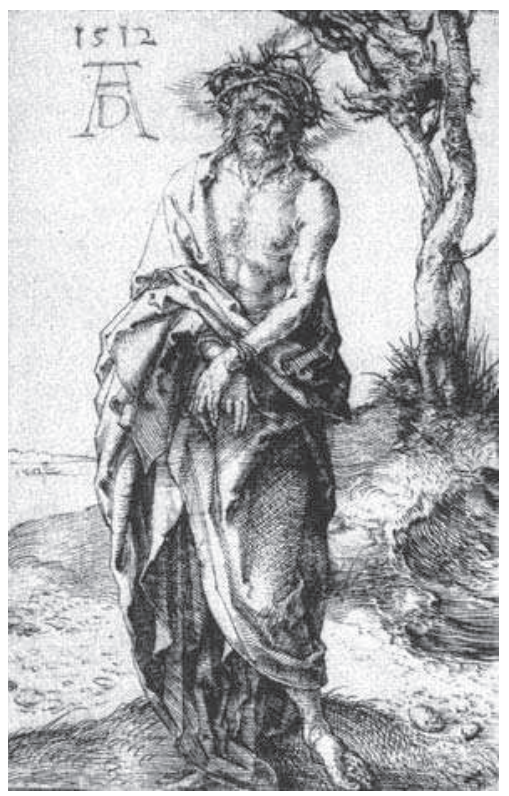

1. ALBERTO DURERO. Ecce-Homo, 1512 . Calcografía a la punta seca.

compartida por la comunidad de creyentes ${ }^{4}$. Estas imágenes, pues, suponen una interpretación "cismundana" de la persona de Cristo: no muestran propiamente la realidad sagrada, sino la experiencia que de ella tienen los hombres, en un intento de acercar, hasta hacerlo asequible, lo divino, lo trascendente, lo extraordinario, "como una realidad próxima, corpórea y tangible, que se incorpora a nuestro mundo y que nos arrastra a penetrar en el suyo" 5 .

Esto parece cumplirse especialmente en los bustos, de directa e íntima comunicación devota. Asimismo puede descubrirse en ello un aprendizaje moral en cuanto al valor del sufrimiento, mediante la identificación del devoto con el mismo Cristo sufriente. Como escribe Freedberg, "no eran sólo las recargadas expresiones de dolor y emoción las que atrapan al espectador, sino también la impresión que éste recibía de poder sentir en sí mismo el sufrimiento y la presencia"6, adquiriendo un matiz ascético y ejemplarizante. Fray Luis de Granada lo expresa meridianamente, continuando su devota meditación sobre el Ecce Homo: "Y no pienses esto como cosa ya pasada, sino como presente; no como dolor ajeno, sino como tuyo propio. A

4 GUARDINI, R.: Imagen de culto e imagen de devoción. Sobre la esencia de la obra de arte. Madrid, 1960 págs. 13-35. Por extenso en LÓPEZ MUÑOZ, J. J.: "Notas para una teoría de la imagen procesional", en Primer Simposio Nacional de Imaginería. Actas. Sevilla, 1995, págs. 157-159.

5 OROZCO DÍAZ, E.: El teatro y la teatralidad del Barroco. Barcelona, Planeta, 1969, pág. 146.

6 FREEDBERG, D.: El poder de las imágenes. Estudios sobre la historia y la teoría de la respuesta. Madrid, Cátedra, 1992, pág. 280. 
ti mismo te pon en lugar del que padesce, y mira lo que sintieras si en una parte tan sensible como en la cabeza te hincases muchas y muy agudas espinas que penetrasen hasta los huesos..."7.

El carácter de espiritualidad ejemplar, tan raro en la proposición de los modelos heroicos de los santos, es aquí claramente perceptible y sale reforzado por los valores y misiones confiados a estas representaciones. La espiritualidad de la catolicidad militante de la Contrarreforma exalta la esencial cualidad ética del misterio de la redención del género humano. Las reflexiones de Luis de la Palma, en su Historia de la Sagrada Pasión, parecen confirmarlo: "quiso el Señor que, para sus amigos y fieles imitadores, la afrenta y el dolor fuesen como dos joyas de inestimable precio, las cuales Él en su reino dejaba vinculadas a su corona" 8 . Por otro lado, su cualidad ritual, que encuentra en los mecanismos de la retórica sus modelos de inmediatez y eficacia, abunda en la inmanencia de estas imágenes, tan cara a la modernidad, potenciando el impacto emocional sobre el devoto. Por ello recomendaba Fray Luis de Granada: "Demás desto conviene en todos estos pasos tener a Cristo ante los ojos presente, y hacer cuenta que le tenemos delante cuando padesce, y tener cuenta no sólo con la historia de su Pasión, sino también con todas las circunstancias della, especialmente estas cuatro (...): quién padesce, por quién padesce, cómo padesce, por qué causa padesce" 9 .

A esas preguntas parecía querer responder el arcediano Mateo Vázquez de Leca con una imagen de Cristo crucificado que contrató con Martínez Montañés, (el Cristo de la Clemencia de la Catedral de Sevilla) al especificar en el contrato que Cristo aparecería "con la cabeza ynclinada sobre el lado derecho, mirando a cualquier persona que estuviere orando al pie dél, como que le está el mismo Cristo hablándole, y como quejándose que aquello que padece es por el que está orando, y assí a de tener los ojos y rostro con alguna severidad...".

A la misma conclusión llegaba el cartujo de Miraflores, Fray Antonio de Molina, en sus Exercicios espirituales, al plantear la directa interpelación de Cristo al devoto, en quien éste halla espejo de suma perfección moral. "Mira, -le dice Cristo-, á qué extremo de miserias me han traído tus pecados... Considera bien este hombre, que ves presente, imprime esta figura en tu corazón, y aprende en ella á despreciar las honras, riquezas, deleytes, prosperidades, y todas las cosas que el mundo busca, y estima, y abrázate con la pobreza, y deshonra, menosprecio, y trabajos, persecuciones, dolores, y adversidades; y cree, que en estas cosas consiste tu felicidad: y si te precias de mi Discípulo, y deseas serlo de verdad, procura imitar esta humildad, obediencia, mansedumbre, paciencia, perfecta caridad, con que amo, y deseo la salud de los que me están aborreciendo, y atormentando"10.

7 "Compendio de la doctrina espiritual", capítulo XV, en Obras..., t. III, pág. 250.

8 PALMA, L. de la: "Historia de la Sagrada Pasión”, en Obras. Madrid, BAC, 1967, pág. 203; cit. SÁNCHEZ LÓPEZ, J. A.: El alma de la madera. Cinco siglos de iconografía y escultura procesional en Málaga. Málaga, 1996, pág. 153.

9 Obras...op. cit., t. III, pág. 246.

10 Exercicios espirituales. De las excelencias, provecho y necesidad de la oración mental. Barcelona, 1776; 


\section{2: artículos Juan Jesús López-Guadalupe Muñoz}

Todo ello testimonia el alto contenido simbólico que la representación del Ecce Homo posee, aislada del propio episodio evangélico del que dimana. Así lo afirma Martínez Medina: "es una imagen simbólica más que narrativa, es como el resumen de la Pasión salvadora del Hijo de Dios, que se hace hombre"11. Sin referirse a un hecho concreto de la Pasión, antes bien como referencia múltiple a ella, supone la representación plástica de todo el drama, así como de todo su contenido ideológico, tan importante en los escritores espirituales de la Contrarreforma.

Ya afirmó en varias ocasiones Orozco Díaz la mutua influencia que debe suponerse entre escritores e imagineros ${ }^{12}$. Con frecuencia los escritores instaban al lector a comprobar en la imagen la realidad de la escena. La breve selección de testimonios aquí recogidos no hace sino poner aún más de manifiesto lo que ya de por sí es evidente: textos e imágenes son distintas manifestaciones insertas en una misma corriente espiritual y de pensamiento, no ajena a las necesidades reales e individuales de la conciencia personal, pero también atentas a una labor de adoctrinamiento moral colectivo. En este sentido, estas imágenes del Ecce Homo, como compendios o síntesis de la Pasión, constituyeron con toda probabilidad idóneos refuerzos de la predicación. Los ejemplos propuestos por Orozco para esto también son varios, y en todos ellos se trasluce un profundo estudio de la experiencia humana de lo trascendente, proyectándola en actitudes de captación, más a través de lo emocional que de lo racional. En esta línea de pensamiento, San Juan de la Cruz opinaba sobre las imágenes que "las que más al propio y vivo están sacadas, y más mueven la voluntad a devoción, se han de escoger, poniendo los ojos en éstas más que en el valor y curiosidad de la hechura y su ornato"13.

Con todo, una adecuada comprensión ética e histórica del Barroco católico, atenta a las necesidades espirituales individuales, permite afirmar la pluralidad de los modelos de su retórica, aun dentro de una suerte de estructura ideológica de conductismo cultural y moral, de perfecta adhesión a sus mentores. Sin duda, la dualidad representativa del Ecce Homo en Granada, entre el busto y la figura completa, es reflejo de esta realidad.

IMAGEN DE DEVOCIÓN E IMAGEN DE PROCESIÓN.

Como es bien sabido, en la escuela granadina de escultura existe una franca propensión a la imagen aislada e individualizada, incluso de pequeño formato, exigiendo una concentración de recursos técnicos y expresivos, prácticamente limitada

citado por MARTÍNEZ MEDINA, F. J.: Cultura religiosa de la Granada renacentista y barroca. Estudio iconológico. Granada, Universidad, 1989, pág. 277.

11 lbídem., pág.76.

12 OROZCO DÍAZ, E.: "Reflexiones sobre nuestra imaginería", Vientos del Sur, 1, Granada, 1943, págs. 36-

37; Manierismo y Barroco. Salamanca, Anaya, 1970, págs. 63-143.

13 Subida al Monte Carmelo, libro $3^{\circ}$, XXXV, 3. Abúndese en LÓPEZ-GUADALUPE MUÑOZ, J. J.: "Mística y naturalismo. Pablo de Rojas, San Juan de la Cruz y el Nazareno de los Mártires de Granada", Boletín de Arte, 26-27, Málaga, 2005-2006, págs. 253-256. 
al gesto, en ocasiones rayana en el virtuosismo. Estas imágenes entran por los sentidos, atañen directamente a los sentimientos y devociones de los fieles; se reducen de tamaño e incluso intiman su expresión. Pasan de templos y calles a oratorios privados y casas particulares, como imágenes de alcoba, según la recomendación del propio San Juan de la Cruz de "escoger el lugar más apartado y solitario que pudieras, y convertir todo el gozo de la voluntad de invocar y glorificar a Dios..."14. Se subraya el carácter devocional por encima del cultual.

De este modo, estas imágenes — fundamentalmente en pequeño formatose convierten en objeto de prácticas cultuales individuales, privadas e incluso domésticas, actualizando la meditación sobre el misterio pasional completo en un compendioso y sintético tracto, con una breve pero precisa punción ascético-purgativa en clave de ejemplaridad, jugando la esencial baza contrarreformista de la humanidad de Cristo y la asimilación a ella del resto del género humano. Se advierte con total nitidez en los bustos de Dolorosa, que no representan ningún episodio concreto, sino que aíslan, resumen y actualizan el drama de la redención, adecuándose a la perfección a ciertas prácticas como la "composición de lugar" ignaciana.

Idénticos valores pueden apreciarse en las esculturas de tamaño natural, más aptas para retablos y procesiones. Conviene puntualizar la certidumbre de que algunas de estas imágenes de gran formato nunca fueron procesionadas, asumiendo la significación propuesta en los bustos como imágenes de devoción únicamente. Pero es igualmente cierta la existencia de escultura procesional en Granada, sobre la cual la crítica suele pasar de puntillas, sin analizar contenidos e intereses. $Y$ es que ciertamente es menos distintiva de la escuela granadina, pero no por ello de menor interés y valía artística, así como menos sintomática de las necesidades espirituales y devocionales de su tiempo. De hecho, aunque algunas imágenes no se concibieran específicamente para su pública exhibición por las calles, era latente en ellas su potencial procesional.

Esta contraposición, pues, entre imágenes de devoción e imágenes de procesión requiere matizaciones más allá de las únicas diferencias de formato. El tiempo ha querido, sin embargo, que algunas imágenes hayan adquirido en nuestros días el carácter procesional que sólo excepcionalmente tuvieron, por lo que resulta más práctico dividirlas en atención a su formato. Por otra parte, la indagación acerca de la escultura procesional granadina, así como de la procedencia de algunas de las piezas que aquí se comentan, permiten revisar los conocimientos que sobre ellas y la actividad procesional de las cofradías de penitencia en Granada se tenían hasta el momento. De este modo, se analizarán por separado la secuencia de imágenes del Ecce Homo de pequeño y gran formato, aportando ciertas novedades documentales e hipótesis para algunas de ellas.

14 Subida... op. cit., libro $3^{\circ}, \mathrm{XL}, 2$. 


\section{Q: artículos Juan Jesús López-Guadalupe Muñoz}

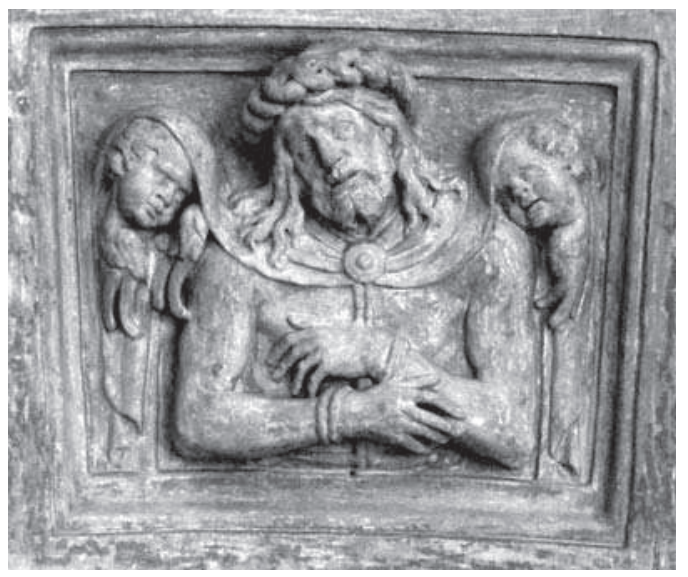

2. DIEGO SILOÉ Ecce-Homo, hacia 1530-1540. Granada, Monasterio de San Jerónimo.

\section{El ECCE Homo granadino de busto.}

Este tema del Ecce Homo, considerado generalmente como la quintaesencia de la escultura granadina del Barroco, posee en ésta mayor tratamiento y peso específico que en ninguna otra escuela española, dato que se revaloriza justamente en los contenidos ideológicos y devocionales ya apuntados. Contando con algunas realizaciones más antiguas, como el relieve en tondo en la puerta de los Colegios de la Catedral (ha. 1530) y en una portada del claustro del monasterio de San Jerónimo [2], ambas de Siloé, y un busto en madera policromada - poco posterior- en la iglesia de San Matías, el definitivo auge de este tipo se produce de la mano de los hermanos García en las últimas décadas del siglo XVI y primeras del XVII. Se trata de unos poco documentados escultores, a los que precisamente la unidad estilística de un buen número de versiones del Ecce Homo en barro o madera sirvió al profesor Orozco Díaz para actualizar su memoria y rehacer su catálogo, recibiendo justamente el apelativo de "escultores del Ecce Homo"15. Comprende un conjunto de obras de calidad diversa, pero de una coherencia estética indudable.

Las tipologías de estas esculturas son variadas, desde el altorrelieve de busto (colección del Ayuntamiento de Granada - pero procedente del convento del Ángel Custodio [3] —, San Justo, Carmelitas Calzadas, Santa Inés, retablo mayor de Santa María de la Alhambra o retablo del convento de los Ángeles, todos ellos en Granada, y otros en la Catedral de Cádiz y en el Hospital de la Caridad de Sevilla) o sólo la cabeza (convento granadino de Santa Isabel la Real) hasta las figuras exentas, éstas

15 OROZCO DÍAZ, E.: "Los hermanos García, escultores del Ecce Homo", Cuadernos de Arte, I.1, Granada, 1936, págs. 1-19; "Nuevas obras de los hermanos García", Cuadernos de Arte, I.2, Granada, 1936, págs. 331-334; y "La estética de Montañés y su formación granadina", en Martínez Montañés y la escultura andaluza de su tiempo. Madrid, Dirección General de Bellas Artes, 1972, págs. 127-136. 


\section{2: artículos Entre la narración y el símbolo: Iconografía del Ecce Homo...}
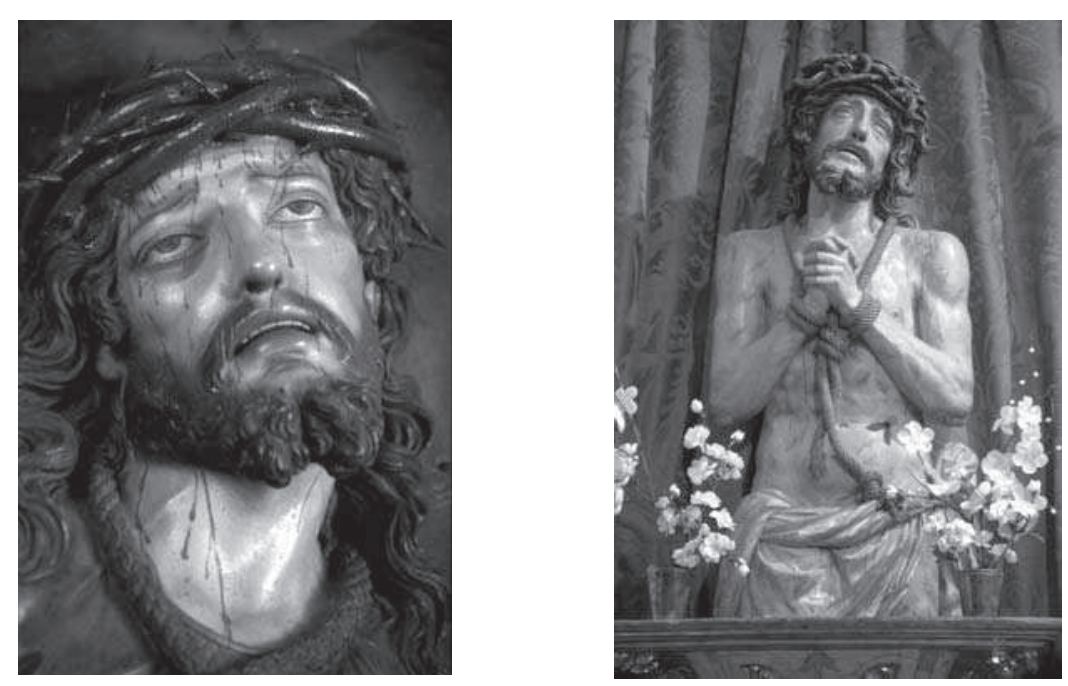

3. Hermanos García. Ecce-Homo (finales del siglo XVI o principios del siglo XVII). Granada, Ayuntamiento [foto: Carlos Torrens].

4. Hermanos García. Ecce-Homo (finales del siglo XVI o principios del siglo XVII). Granada, Convento del Santo Ángel Custodio.

en cuatro modalidades: la figura completa arrodillada y orante — que cabría encuadrar en un episodio diferente y apócrifo, cual podría ser una oración previa a la crucifixión- como la del convento de Santa Isabel la Real y la del Salón Amarillo de la Casa Consistorial; el Cristo sedente contemplando la cruz, claramente vinculado en lo narrativo al tipo anterior, como el conservado en el citado Salón Amarillo y otro en colección particular madrileña; el busto (a veces largo, por debajo de la cintura), normalmente elevando la mirada al cielo, con gruesa cuerda al cuello que anuda también sus manos, como en la Cartuja, San Justo, Ángel Custodio [4] y colegio de Santo Domingo, todos ellos en Granada, el de San Francisco de Priego de Córdoba o el primoroso del Hospital de Nuestra Señora de la Paz de Sevilla16; y, en fin, la sola cabeza, también con la mirada alta, de los que se conservan algunos ejemplares en el Museo de Bellas Artes de Granada, la parroquial de Lanjarón (Granada), en la clausura del convento de San Antón de Granada, en la parroquia de Ohanes de Almería, en la de San Nicolás de Madrid ${ }^{17}$ o en el altar de Jesús Nazareno de la Catedral de Granada ${ }^{18}$. Fuera de esos modelos, sólo una imagen de pequeño for-

\footnotetext{
16 El último fue dado a conocer por CARRERO RODRÍGUEZ, J.: "Una imagen de Jesús orante en el Gólgota de los hermanos García en Sevilla", Laboratorio de Arte, 4, Sevilla, 1991, págs. 317-324.

17 Mal catalogado, creo, como anónimo italiano del siglo XVIII en el catálogo Exposición conmemorativa del Primer centenario de la Diócesis de Madrid-Alcalá. Madrid, Caja de Madrid, 1986, págs. 178-189.

18 El catálogo conocido hasta el momento de los García se completa fundamentalmente con otras imágenes de la Pasión, de entre los que descuella el Crucificado de la sacristía de la Catedral de Granada, que le
} 


\section{Q: artículos Juan Jesús López-Guadalupe Mñ̃oz}

mato atribuido a estos escultores se presenta de cuerpo entero y erguida, como en la Presentación al Pueblo, deliciosa obra conservada en el Convento de Santa Ana de Córdoba.

En las obras de este elenco se prefiere por lo común el pequeño formato y rara vez la figura completa. Se caracterizan por mostrar los tipos humanos fuertes y musculosos que el impulso naturalista de transición entre el Quinientos y el Seiscientos define en favor de una mayor valoración plástica de la figura, teniendo como correlato las series de Pablo de Rojas. Este mismo naturalismo impulsa su afán minucioso y realista, favorecido la mayoría de las veces por las posibilidades plásticas del barro, exuberante en detalles y policromía. Se agudiza la concentración expresiva en el rostro, con pesadas coronas de espinas, modeladas o talladas en la propia cabeza y generalmente entrelazadas con sus retorcidos mechones, en un desarrollo plástico de clara intención dramática. Se acusan detalles de gran fortuna en la escultura andaluza, como la espina que atraviesa la ceja. La unidad de intereses de todos ellos es clara: extremar hasta donde sea posible la impresión en el devoto, provocando la compasión.

Cabeza de serie, sin duda, es el busto que se conserva en la Cartuja de Granada, quizás el que ponderaba el Conde de Maule en el convento del Carmen ${ }^{19}$, obra maestra a la hora de considerar la fuerza comunicativa que ofrece su cercana contemplación, la impresión que produce su patética desnudez y la sensación de angustia y sufrimiento que trasciende la figura, abarcando el cuerpo y el espíritu. Orozco recordaba ante ella los versos de Juan López de Úbeda: "Y aquel cuerpo hermoso / que pudiera ser del sol envidiado / de crueles azotes matizado / estaba denegrido y sanguinoso" 20 . En efecto, su realismo raya, por una vez, la expresión patética, que tan ajena es a la escultura granadina, y se desgrana en los pormenores del castigo, que meditaba Fray Luis de Granada: "sus espaldas no son espaldas, sino heridas y cardenales: y heridas inverosímiles pero que acentúan la parte del dolor y del destrozo material; la piel se desgarra, y para acentuarlo más, su espesor llega a ser como el del cuero, viéndose a través de ellas la blancura del hueso"21. Parece recoger toda su amargura entre las manos entrelazadas que aprieta sobre el pecho, dramatización gestual de vivo impacto emocional en el espectador.

La estética de estos bustos y relieves relacionados con los García constituye un punto y aparte en la escultura granadina, en lo que a patetismo se refiere, quizás fruto de contactos foráneos, siendo muy sugestiva la vinculación estética con Núñez Delgado. Sin embargo, sirven para apuntar un tema de excepcional fortuna entre

atribuyó Sánchez-Mesa (anotación en SALAS, X. de: Noticias de Granada, reunidas por Ceán Bermúdez. Granada, Universidad, 1966, pág. 31, nota 57).

19 "En la parte superior del altar de la Virgen del Carmen, una efigie de medio cuerpo de la coronación de Jesucristo es de los Garcías" (CRUZ Y BAHAMONDE, N. de la: Viaje de España, t. XII. Cádiz, 1812, págs. 249-250).

20 OROZCO DÍAZ, E.: "Los hermanos García..." op. cit., pág. 9.

21 Cit. SÁNCHEZ-MESA MARTÍN, D.: "El arte del Barroco. Escultura, pintura y artes decorativas", en Historia del Arte en Andalucía, t. VII. Sevilla, Gever, 1991, pág. 124. 


\section{2: artículos Entre la narración y el símbolo: Iconografía del Ecce Homo...}
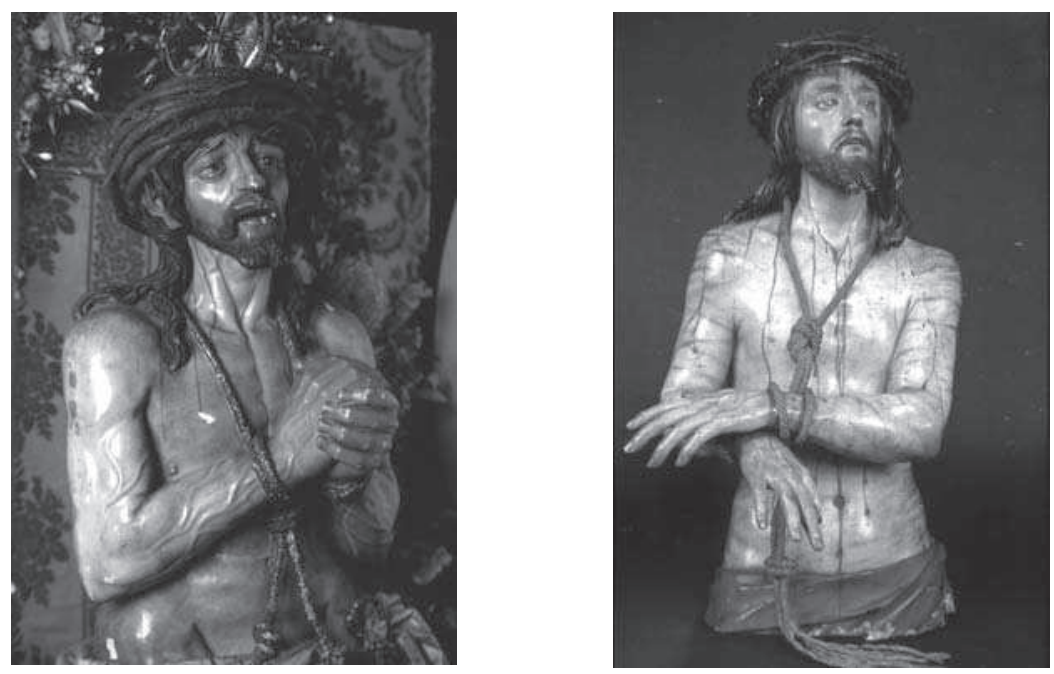

5. Atribuido a ALONSO DE MENA. Ecce-Homo, primera mitad del siglo XVII. Granada, Convento de San Antón [fotografía: Carlos Torrens].

6. PEDRO DE MENA. Ecce-Homo, 1673. Madrid, Convento de las Descalzas Reales.

nosotros, así como para abrir cauces resueltamente naturalistas en las experiencias plásticas, de modo paralelo a las de Pablo de Rojas, pero éste en clave de contención y clasicismo, caracteres que marcarán un sello de serenidad y equilibrio plástico en la escultura granadina.

Ya en el Seiscientos, encontramos un par de ejemplares del Ecce Homo atribuibles a Alonso de Mena, elenco corto para quien, sin embargo, abundó en los temas de la Pasión de Cristo. Se trata de un busto en la iglesia del Carmen de Écija, fechado en 1644, y otro de igual formato en la clausura del convento de San Antón de Granada, directamente entroncado con la experiencia de los García, que ahora damos a conocer [5]. Pero será con su hijo Pedro cuando el tema adquiera verdadera carta de naturaleza "granadina", complementado idóneamente con los bustos de Dolorosa, demostrando una vez más su calidad de fiel intérprete del sentimiento devoto y de la religiosidad de su tiempo.

Junto a un par de figuras completas cercanas a su estilo, destaca en la producción de Pedro de Mena una sobresaliente serie del Ecce Homo de busto, de la que resultan paradigmáticos los ejemplares conservados en el Museo de Bellas Artes de Granada y en el convento de las Descalzas Reales y Museo Nacional de Artes Decorativas en Madrid. Son figuras de plástica sobria, serenas, sinceramente humanas, con expresión contenida, interpretadas con una minuciosidad descriptiva paralela a la de los escritores místicos. Existen en todos ellos variaciones y matices, 


\section{Q: artículos Juan Jesús López-Guadalupe Muñoz}

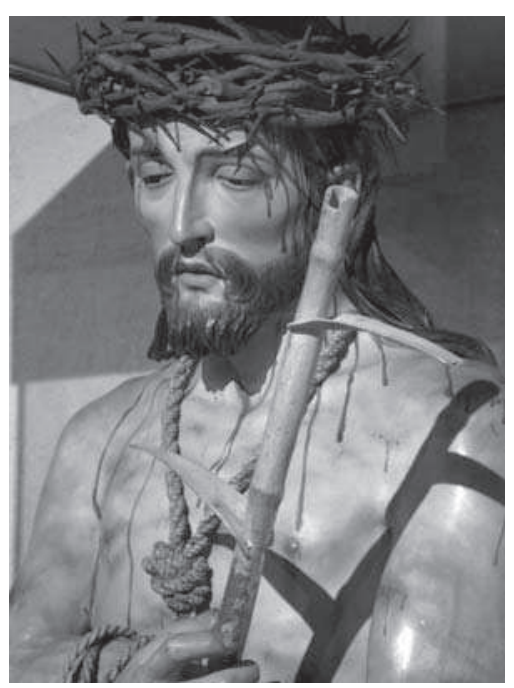

7. BERNARDO DE MORA. Ecce-Homo, 1659. Granada, Capilla Real.

"que demuestran una espontánea labor de las gubias, que interpretan cómo sentía y vivía el artista en su religiosidad el tema"22.

El granadino sólo llega hasta la mitad del torso, mientras los madrileños (seguramente el del Museo de Artes Decorativas derivado del de las Descalzas) son de media figura, agrupando las manos atadas hacia su derecha, en un gesto resuelto con naturalidad y elegancia, concentrando la expresión en la inmensa tristeza del rostro. Parece resultar el más sobresaliente el de las Descalzas Reales, firmado y fechado por Mena en Málaga en 1673, cuidado y exquisito, como seguro encargo de la Corte. En todos ellos frecuenta esos tipos humanos bien modelados y de faz afilada, aumentada por su barba partida. Tuvo bastante fortuna el modelo pues en diversas clausuras madrileñas se conservan obras en su estela, aunque no de su mano 23 .

Anterior a esta serie es el Ecce Homo de uno de los retablos-relicarios de la Capilla Real de Granada [7], encargado a Pedro de Mena, quien traspasó el encargo a su pariente Bernardo de Mora en 1659. De modelado no muy apurado, su expresión resignada no logra el clímax expresivo de Pedro de Mena o el efecto angustiado de su hijo José. La ceja derecha atravesada por una espina de la corona lo sitúa en una larga secuencia de artistas, sobre todo andaluces, que emplean este efectista pormenor descriptivo. No obstante, marca perfectamente los tiempos de lectura devocional en esta imagen, muy en el tipo granadino.

22 Ibídem, pág. 231.

23 La serie de este tipo iconográfico, vinculada más o menos cercanamente a Mena, es muy amplia. Una reciente y completa revisión véase en GILA MEDINA, L.: Pedro de Mena, escultor (1628-1688). Madrid, Arco/Libros, 2007, págs. 175-181, 187-191 y 194-197. 


\section{Q: artículos Entre la narración y el símbolo: Iconografía del Ecce Homo...}

8. JOSÉ DE MORA. EcceHomo, último cuarto del siglo XVII. Granada, Convento de Agustinas del Corpus Christi.

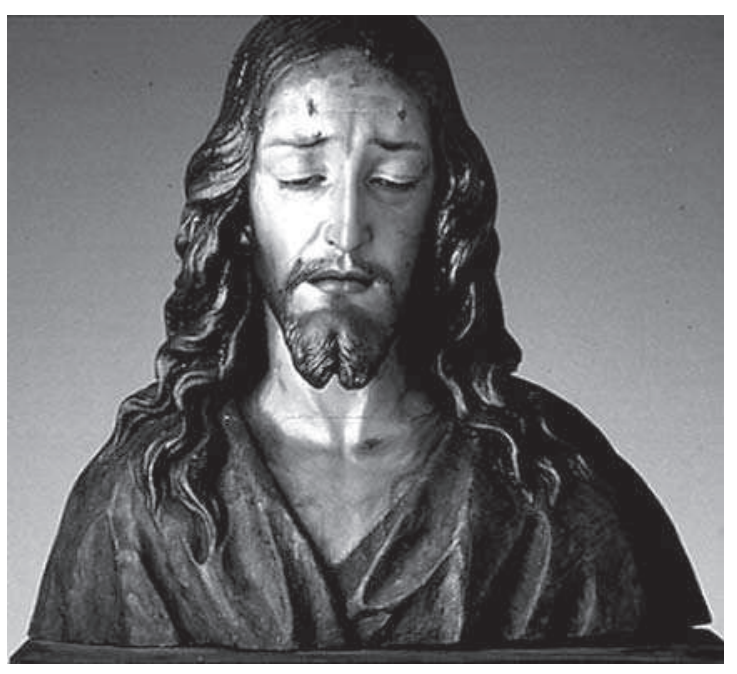

Este tipo cobra nuevo vigor en manos de su hijo José, autor de la otra gran serie de bustos del Ecce Homo en Granada, normalmente formando pareja con la Dolorosa, lo que subraya el carácter simbólico y devocional (en detrimento de lo estrictamente narrativo) que alcanza el tipo avanzado el siglo. Constituye tema predilecto en su producción artística, en donde mejor muestra su personalidad, más quizás en las Dolorosas que en el Ecce Homo. En formato de busto, frecuenta la figura recortada a la altura de los hombros. Su serie, fechable en el último cuarto del siglo XVII, presenta originalidad y calidad parejas a las de Mena. Junto a la pareja del convento de las Maravillas de Madrid de su época en la Corte ${ }^{24}$, su serie granadina parece arrancar del más realista de la parroquia de la Magdalena, para mantener la intensidad de expresión, más espiritual y menos dramática, en el del Museo de Bellas Artes de Granada — procedente del convento del Ángel Custodio—y en el de la clausura de las Agustinas del Corpus Christi [8], este último muy dibujístico y apurado de modelado, logrando la mayor emoción religiosa en el del convento de Zafra. La serie incluye en la monografía de Gallego Burín la pareja de Ecce-Homo y Dolorosa del convento de Santa Isabel la Real25. La adscripción de la Dolorosa es indudable, no así la del Ecce-Homo, que encuentro cercano a la estética de Pedro de Mena ${ }^{26}$. Las diferencias en cuanto a modelado somero, de superficies amplias y aplanadas, y cabellos lacios fueron interpretadas por Gallego Burín como la resolu-

24 Como en el caso de Mena, las clausuras madrileñas conservan obras afines a este tipo, aunque no de su mano, lo que habla bien de la aceptación popular del modelo y su formato, convirtiéndolo en objeto de gran demanda.

25 GALLEGo BURÍN, A.: José de Mora. Su vida y su obra. Granada, Universidad, 1925 (ed. facsímil en Granada, Universidad, 1988), págs. 171-172.

26 Así lo ha advertido recientemente GILA MEDINA, L.: op. cit., pág. 197. 


\section{2 artículos Juan Jesús López-Guadalupe Muñoz}

ción plástica de una nueva tendencia expresiva de su autor, cuando justamente son rasgos estilísticos que abonan esta otra propuesta de autoría. Sin embargo, las dos imágenes fueron recibidas como donación ya formando pareja ${ }^{27}$, lo que no impiden que sean de distinta gubia.

En todos ellos el interés del escultor se centra en la proyección espiritual, sublimando los tipos individuales casi en concreción mística, con creciente propensión a la languidez y la melancolía, a cierta deformación de radicalización expresiva incluso, encerrando las figuras en su perfil como Cano. "Extáticos y contemplativos, o doloridos y tristemente resignados", así los definía Gallego Burín ${ }^{28}$, en tono de sublimación intelectualizada, variaciones de un tipo humano perfectamente reconocible de cejas enarcadas, ojos hundidos, nariz afilada, mejillas huidizas, y barba ligera y bífida. Son imágenes para emocionar pero no para arrebatar, expresiones acabadas del sentimiento religioso del autor, de consumo devoto e íntimo, y de gran eficacia ritual y espiritual. La serie se corona y perfecciona con una figura completa a tamaño natural que más abajo se analizará.

El tema se prolonga en sus seguidores, comenzando por su hermano Diego, que recoge los modelos de José en su pareja de Ecce Homo y Dolorosa del Museo de Bellas Artes de Granada, también procedentes del convento del Ángel Custodio, más suaves tanto en lo plástico como en lo expresivo. El más cercano en la intensidad de los bustos de José de Mora es José Risueño en el que Sánchez-Mesa le adjudica en la Capilla Real de Granada ${ }^{29}$, hasta entonces atribuido a Mora a la vista de la comunión de intereses estéticos que presentan. Prolonga la figura hasta la cintura con la cabeza baja y las manos atadas sobre el pecho, intimando la expresión. Aún en Ruiz del Peral y otros epígonos de la escuela se frecuentará este tema, con diversa fortuna, como demuestra la endeble pareja de Ecce Homo y Dolorosa que hoy se conserva en la colegiata de Huéscar (Granada). Las iglesias granadinas abundan en estas imágenes de busto, sin duda una de las creaciones más exquisitas y peculiares del arte granadino, lo que en ocasiones ha forzado la injusta minusvaloración de las representaciones de figura completa a tamaño natural, cuya memoria queremos reivindicar.

\section{El Ecce Homo de figura completa en Granada. Algunos ejemplos.}

Pese a la justa fama alcanzada por el Ecce Homo de busto granadino, no es desdeñable ni menor la producción de imágenes del mismo tema de figura completa

27 CALVO CASTELLÓN, A.: "El Ecce Homo y la Dolorosa de José de Mora, en el Monasterio granadino de Santa Isabel la Real, a la luz de una documentación inédita", Cuadernos de Arte e Iconografía, III. 5, Madrid, 1990, págs. 71-79. La donación se efectúa en 1791 y se acompaña de una tasación realizada por el escultor académico Jaime Folch que afirma la autoría de José de Mora. Sin embargo, el estilo de la imagen del Ecce-Homo contradice claramente esta aseveración.

28 GALLEGO BURÍN, A.: op. cit., pág. 148.

29 SÁNCHEZ-MESA MARTíN, D.: José Risueño, escultor y pintor granadino (1665-1732). Granada, Universidad, 1972, págs. 188-189. 


\section{2: artículos Entre la narración y el símbolo: Iconografía del Ecce Homo...}
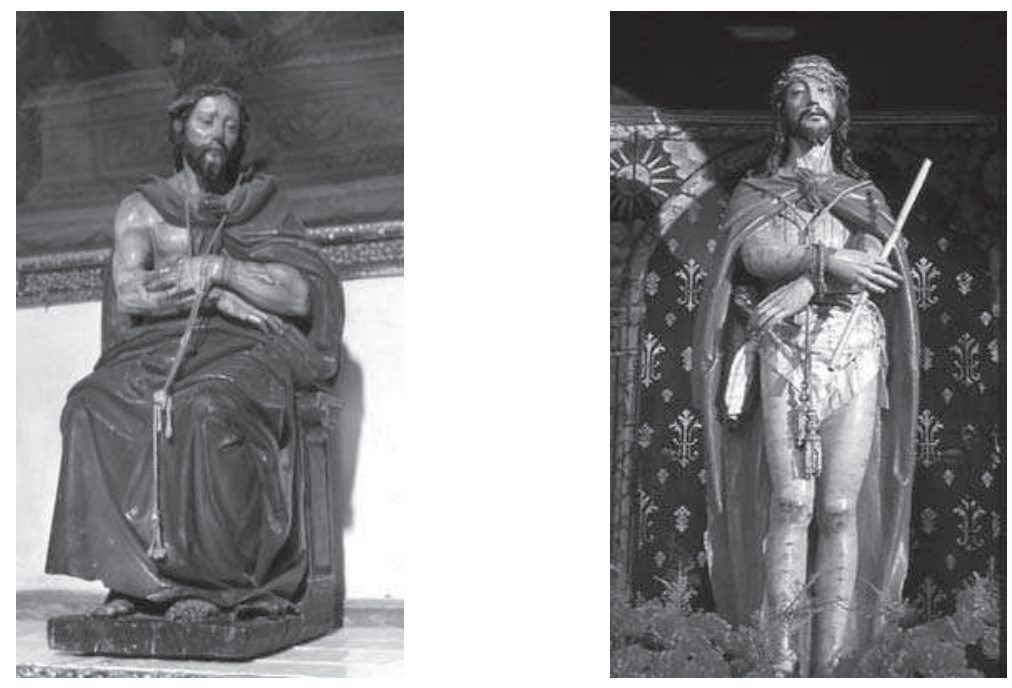

9. Bernabé DE GAVIRIA (?). Jesús de la Humildad, último cuarto del siglo XVI. Granada, iglesia de San Ildefonso.

10. Taller de PEDRO DE MENA. Jesús de la Humildad, segunda mitad del siglo XVII. Granada, iglesia de Santa María de la Alhambra.

a tamaño natural, si bien menos frecuente, aunque esto último es evidente que obedece menos a consideraciones devocionales o estéticas que a condicionantes materiales. Por otro lado, la pretendida "aprocesionalidad" de la imaginería granadina se ve contestada por una sostenida actividad procesional, con lógicos altibajos, de muchas imágenes devocionales durante toda la Edad Moderna. En ella se contempló siempre la escena del Ecce Homo, devoción propia de varias hermandades durante este periodo. Por otro lado, documentos y crónicas testimonian el auge devocional de algunas imágenes que por su advocación debieron corresponder al tipo iconográfico estudiado. Sin embargo, su pertenencia a conventos desamortizados dificulta su exacta localización. En esta ocasión, se propone una puesta al día, incluso con documentación inédita, de los conocimientos referidos a seis de estas imágenes y sus devociones.

La primera de ellas es un Ecce Homo [9] que se conserva en la parroquial de San Ildefonso. Cristo aparece sentado, envuelto en una clámide roja que sólo deja desnudos los brazos, un hombro y parte del pecho. Las manos se cruzan ante él, apresadas por cordón de oro postizo, mientras vuelve el rostro hacia su izquierda. Su sede es un sillón, con brazos rematados en volutas. Aunque carente hoy de corona de espinas y de cetro de caña, es una perfecta representación de la burla de Cristo durante su Coronación. 


\section{2. artículos Juan Jesús López-Guadalupe Muñoz}

Desde el punto de vista estilístico, la imagen demuestra gran vigor plástico, tanto en su fornido tipo humano como en el desenvuelto plegar de paños, resuelto a base de grandes y contrastados planos, cayendo de modo natural, dejando incluso ver de modo elegante los pies de Cristo. En cuanto al rostro, recuerda los modelos achatados de Pablo de Rojas, con pómulos salientes y cabello en grandes mechones. El tono general de la figura exalta su plena valoración plástica, incluso en su lado posterior, lo que la hace apta para procesionar. Además de beber en fuentes pictóricas y de grabados, parece humanizar el modelo de clasicismo envarado y casi arrogante de Juan Bautista Vázquez el Mozo en el retablo mayor del monasterio de San Jerónimo de Granada, que también deja un hombro y parte del pecho descubierto, recurso tan efectista como "heroizador" de la figura. En el círculo artístico generado en torno a dicho retablo debió completar su formación Pablo de Rojas, resultando esta escultura muy cercana a la estética del maestro alcalaíno, quizás fruto de las gubias de alguno de sus seguidores, como Bernabé de Gaviria.

En cuanto a la procedencia de la imagen, parece coherente, ya que no consta en los inventarios de la parroquial, que llegara a ésta procedente del contiguo convento desamortizado de la Merced, de mercedarios calzados, junto con otras esculturas, entre ellas la titular del cenobio, la Virgen de las Mercedes. En él existió una hermandad penitencial, la de la Sangre de Jesucristo, que debió fundarse en el último cuarto del siglo XVI, que al parecer contemplaba varios misterios de la Pasión, acordando con la fecha en que estilísticamente cabe situar esta imagen. En la segunda mitad del XVII desapareció y el testigo parece recogerlo en la centuria siguiente la hermandad de Jesús de la Humildad, que daba culto a una imagen con corona de espinas, cetro de plata y cordón de oro, procesionando también varios "pasos" de la Pasión el Miércoles Santo ${ }^{30}$. Participaba en ella otra hermandad, con el título de Jesús Nazareno, que quizás sea la misma; de hecho, en una relación de las procesiones de Semana Santa de 1791 aparece con este último título, procesionando el mismo día que la anterior los "pasos" de Jesús atado a la columna (que bien pudiera ser otra imagen que se conserva en la misma parroquial), Jesús de la Humildad, Jesús Nazareno, el Crucificado, San Juan Evangelista y María Santísima ${ }^{31}$. Por tanto, parece verosímil considerar esta imagen como la perteneciente a la cofradía de la Sangre de Jesucristo a finales del siglo XVI y primera mitad del XVII, y a la de Jesús de la Humildad o Jesús Nazareno ya en el Setecientos. Recuérdese a este respecto que Pablo de Rojas ha sido el imaginero que mejor se ha documentado en su relación con las cofradías y en la ejecución de imágenes procesionales ${ }^{32}$, marcan-

30 LÓPEZ MUÑOZ, M. L.: Contrarreforma y Cofradías en Granada. Aproximación a la historia de las cofradías y hermandades de la ciudad de Granada durante los siglos XVII y XVIII (tesis doctoral inédita) Universidad de Granada, 1992, pág. 561.

31 Archivo de la Real Chancillería de Granada, 322-4446-2. Al respecto vid. LÓPEZ MUÑOZ, M. L.: "Semana Santa en Granada a finales del siglo XVIII", Descendimiento, 11, Granada, 1996, págs. 31-37.

32 LÓPEZ-GUADALUPE MUÑOZ, M. L. y LÓPEZ-GUADALUPE MUÑOZ, J. J.: Nuestra Señora de las Angustias y su Hermandad en la época moderna. Notas de historia y arte. Granada, Comares, 1996, págs. 
do claramente un itinerario- plástico expresivo para los continuadores de su estética en un momento, además, de verdadera eclosión de las imágenes devocionales con actividad procesional (sea reglada como eventual). Por otro lado, se tiene documentada la construcción de un retablo para una capilla de este convento por el escultor alcalaíno, con anterioridad a 1583, concordando perfectamente con lo hasta ahora expuesto ${ }^{33}$.

Ya del siglo XVII, el profesor Orozco Díaz dio a conocer dos imágenes completas del Ecce Homo, de tamaño natural, relacionadas con el arte de Pedro de Mena, destacando el espléndido ejemplar de la parroquia de Santa María de la Alhambra $(153 \mathrm{cms})$ [10] ${ }^{34}$. Como explica Orozco, esta escultura asume la mayoría de los rasgos estilísticos de Mena, hasta en sus defectos. La imagen está concebida frontalmente, encerrada en el amplio perfil ahusado de un tosco manto que se adelgaza en su caída con gran seguridad técnica; se anuda en el pecho con un lazo, como el de San Ildefonso. Su rigidez, quietud y simetría en su plástica sobria y realista lo acerca a los bustos de Mena, en especial al del Museo de Bellas Artes de Granada. Especialmente el rostro, afilado, de barba partida y ojos almendrados, se asemeja mucho a estas piezas. Al igual que en los bustos, la imagen se concibe como símbolo, con las manos algo levantadas, casi oferentes; en su rigidez, parece la detención de una instantánea. Sin vibración ni dinamismo, ofrece la visión sencilla y simple del hombre ultrajado y maltrecho, con el acento de sinceridad religiosa que Mena y su círculo imprimieron a sus imágenes. Cabe destacar su paño de pureza triangular, al uso en otras imágenes con él relacionadas, y su desnudo blando y realista, pero sin la minuciosidad del mejor Mena. También extraña la simplicidad y poca profundidad del cabello y barba, subrayando un modelado plano y somero en el aspecto general de la figura. Su carácter devocional queda bien manifiesto al haber estado mucho tiempo vestida con manto de terciopelo rojo bordado en oro e incluso paño de pureza adamascado. Debe considerarse claramente como obra de taller, adscrita ya a su etapa malagueña, desde donde siguió surtiendo de imágenes a Granada. Ésta, en concreto, tuvo como destino una iglesia para la que su padre Alonso ya había trabajado, realizando en 1634 un Crucificado que hoy preside el retablo mayor.

Se conocen noticias acerca de una hermandad que le dio culto. Se trata de la cofradía de Jesús de la Humildad, Santísimo Cristo de la Vía Sacra y Santísimo Rosario, que debió surgir a fines del siglo XVII —lo que concuerda con la data propuesta- y sobrevivir durante todo el XVIII, incluso con cierto auge a comienzos del siglo XIX, pero sin actividad procesional, sólo cultual ${ }^{35}$, pareciendo claro que la imagen a la que se rendía culto fuera ésta.

63-70; GILA MEDINA, L.: "En torno a los Raxis Sardo: Pedro de Raxis y Pablo de Rojas en la segunda mitad del siglo XVl", Atrio, 4, Sevilla, 1992, pág. 42

33 Ibídem, pág. 42

34 OROZCO DÍAZ, E.: "Un Ecce Homo desconocido de Pedro de Mena y la interpretación de este tema en la escultura granadina", Goya, 71, Madrid, 1966, págs. 292-299; Centenario de Alonso Cano y su escuela. Catálogo de la exposición. Granada, Caja de Ahorros, 1970, pág. 78, n 78.

35 LÓPEZ MUÑOZ, M. L.: Contrarreforma y cofradías..., págs. 407-408; GILA MEDINA, L., LÓPEZ-GUADA- 


\section{Q: artículos Juan Jesús López-Guadalupe Muñoz}
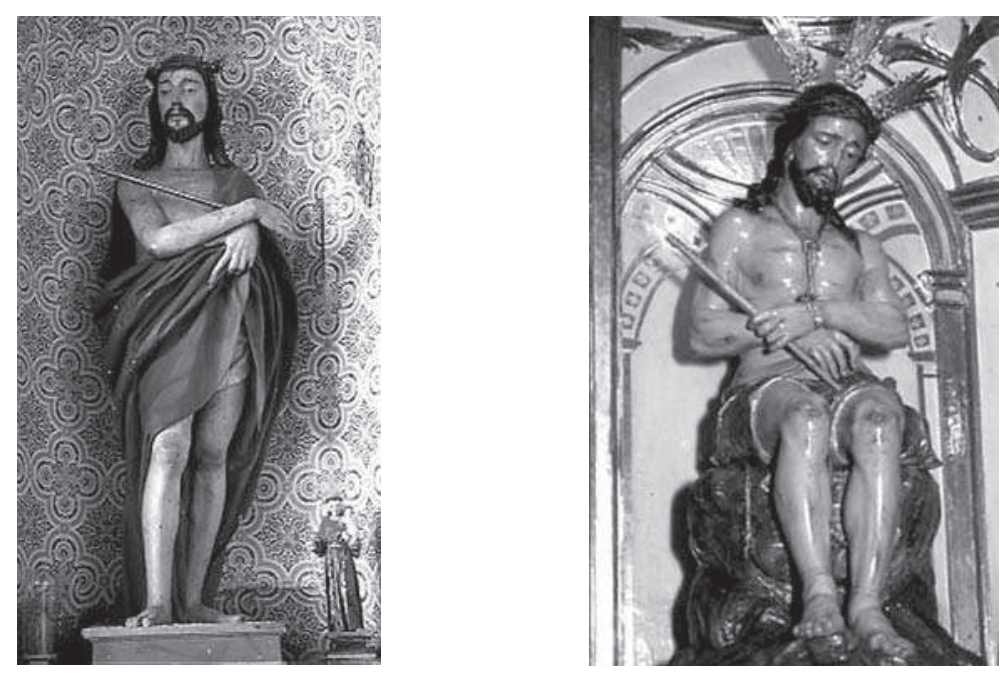

11. Taller de PEDRO DE MENA. Ecce Homo, hacia 1652-1658(?). Granada, clausura del convento de la Encarnación.

12. Anónimo. Señor de la Humildad, hacia 1689. Granada, iglesia de Santa Escolástica (Santo Domingo).

La otra imagen es un Ecce Homo [11] que se guarda en la clausura del convento de la Encarnación. Orozco la considera "innoble y vulgar"36, obedeciendo desde luego a un modelo completamente distinto a la anterior, pero no exento de cierta gallardía en una composición mucho más interesante y estudiada. El dinamismo de la figura está subrayado por el decidido avance de la pierna derecha, el manto que se cruza en abundantes pliegues, el consciente equilibrio entre las manos atadas hacia su izquierda y la cabeza vuelta al lado contrario. En definitiva, un concepto dinámico de la figura nada cercano a los éxtasis en que son sorprendidas muchas de las esculturas de Mena y más ligado a la búsqueda de una figura de clásica elegancia, aunque de resultado adocenando, que parece encontrar, una vez más, su referente en el retablo de San Jerónimo y, sobre todo, en los modelos de Alonso Cano. El modelado resulta aún más sobrio y apurado que el anterior, advirtiéndose el inicio de un paño de pureza semejante. Sí es cierto que el rostro resulta un tanto adocenado y falto de expresión, pero en general la figura parece estar dotada de un punto de distinción, aun siendo una realización de taller. No obstante, es una de las pocas versiones del tema en figura completa que puede ligarse a su estilo.

LUPE MUÑOZ, J. J. y LÓPEZ-GUADALUPE MUÑOZ, M. L.: Los conventos de la Merced y San Francisco, Casa Grande, de Granada. Aproximación histórico-artística. Granada, Universidad, 2002, págs. 63-67.

36 OROZCO DÍAZ, E.: “Un Ecce Homo desconocido...", pág. 296. 
Orozco no data esta imagen, pero quizás pertenezca a los últimos años del artista en su ciudad natal, cuando el regreso a ella de Alonso Cano modifica sustancialmente el rumbo artístico de la escuela granadina. En ese momento, el antiguo taller de Alonso de Mena, regentado ya por Pedro, sostiene una abundante producción, con clientela principalmente conventual. Fruto de la colaboración Cano-Mena son los cuatro santos para el convento del Ángel Custodio (hoy en el Museo de Bellas Artes), en los que pueden adivinarse cierto parentesco en cuanto al tratamiento de paños, como el San José, con respecto al Ecce Homo estudiado, y en otras de pequeño formato, desde luego sobre modelos pictóricos de Cano, que luego repite en el San José de la iglesia de San Nicolás de Murcia, de $1672^{37}$. También antes de marchar a Málaga realizó un importante conjunto de doce esculturas para el convento de Nuestra Señora de la Victoria, de mínimos de San Francisco de Paula, entre 1657 y 1658. Cupiera ver en esta imagen una obra de taller, bajo la directa sugestión del maestro y éste, a su vez, de Cano, quizás para alguno de los encargos referidos.

La imagen del Señor de la Humildad [12] se venera actualmente en la parroquia de Santa Escolástica, correspondiente al templo del convento dominico de Santa Cruz la Real, pero proviene del desamortizado de Nuestra Señora de Belén, de mercedarios descalzos. Representa la Coronación de espinas, devoción de origen centroeuropeo, muy vinculada a la adoración de las reliquias de la corona. La representación ha sido completada en el siglo XX con las figuras de un sayón y de un soldado romano de Eduardo Espinosa Cuadros y dos judíos de Ángel Asenjo Fenoy, con destino a la composición de un "paso de misterio".

Figura de tamaño algo menor que el natural, representa a Cristo sentado en una peña, con las manos atadas ante el pecho, sosteniendo una caña y con la mirada baja. El modelado resulta en general somero, seguro en el tratamiento de las rodillas y delicado en sus manos, realzado en el paño de pureza por la labor de escalfado. El rostro es emocionante y sereno, de severa resignación, con la sinceridad de la devota escultura, enmarcado en mechones bien dibujados. Me parece imagen del último tercio del XVII, cercana a los patrones formales del taller de los Mora, siguiendo quizás el modelo de Bernardo de Mora en el Ecce Homo de la Capilla Real. Muestra clara policromía en semibrillo, matizada a punta de pincel en hematomas y heridas. Para su actividad procesional en el Martes Santo granadino, viste a la espalda clámide morada con bordados en oro.

Fue Bermúdez Pareja el primero en identificar esta imagen con la del convento de Belén ${ }^{38}$. Éste poseyó iglesia bien ornamentada, de modo que el cronista Fray Pedro de San Cecilio calificaba en tono panegírico "que no hay templo en Granada,

37 GÓMEZ-MORENO, Ma E.: "Obras desconocidas de Pedro de Mena", Cuadernos de Arte, III, Granada, 1938, pág. 25; SÁNCHEZ-MESA MARTÍN, D.: "Algunas noticias sobre la obra de Pedro de Mena", Archivo Español de Arte, XL, Madrid, 1967, págs. 252-254.

38 BERMÚDEZ PAREJA, J.: "El convento de Belén”, Cuadernos de Arte, I.1, Granada, 1936, pág. 68, nota 31. 


\section{Q: artículos Juan Jesús López-Guadalupe Muñoz}

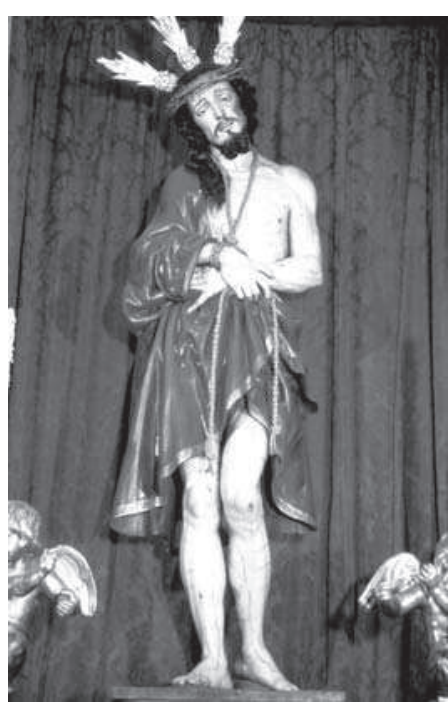

13. JOSÉ DE MORA. Jesús de la Sentencia, principios del siglo XVIII. Granada, iglesia de San Pedro.

ni aún de los muy antiguos que tenga mayor cantidad de efigies, ni que más provoquen a devoción" 39 , insistiendo Jorquera en sus Anales que "estaba adornada de muchas capillas, donde se contempla la Pasión de Jesucristo"40. El título completo de esta imagen era de la Humildad y Paciencia, lo que ha hecho sospechar a Martínez Medina que se trate de un tipo iconográfico distinto, el del descanso o meditación previas a la crucifixión, según modelos pictóricos, entre otros, de Alonso Cano ${ }^{41}$. Sin embargo, su actual disposición, con la caña en la mano, parece apropiada para una representación de la Coronación de espinas, genéricamente atribuible al tema del Ecce Homo.

El gacetillero trinitario Padre Lachica relata lo siguiente sobre el origen de esta imagen: "tráxola a este convento un hombre peregrino, sin saberse quién era éste ni de qué parte la traxo. En martes 18 de octubre de 1689 la entregó a dos religiosos y él desapareció, haviéndola éstos recibido. Hízose el caso notorio a el pueblo, el que movido de tan singular maravilla, consagró a el Señor varias fiestas y se han logrado muchos beneficios por la devoción a este simulacro" 42 . Le dio culto una hermandad que debió nacer poco después, con actividad procesional, pero no penitencial ${ }^{43}$. Aún se conserva hoy una tablilla de indulgencias en su actual capilla en Santo Domingo, concedidas en 1800 por D. Pedro Esteve, obispo de Mérida del Yucatán, reflejando el título completo de la imagen. Desde 1926 es titular de una hermandad de penitencia en su actual templo.

El Ecce Homo de la parroquia de San Pedro [13], actualmente bajo la advocación de Jesús de la Sentencia (168cms.), pone el contrapunto a las dos imágenes que más arriba se relacionaron con Pedro de Mena. La relación de esta imagen con

39 SAN CECILIO, Fr. P. de: Anales de la Orden de Descalzos de Nuestra Señora de la Merced. Barcelona, 1969, pág. 1030.

40 HENRÍQUEZ DE JORQUERA, F.: Anales de Granada. Granada, Universidad, 1934 (ed. preparada por Antonio Marín Ocete), pág. 214; citado por BERMÚDEZ PAREJA, J.: op. cit., págs. 64 y 68.

41 MARTÍNEZ MEDINA, F. J.: op. cit., pág. 285. No obstante, era una advocación frecuente y no siempre ligada a la iconografía citada. Como muestra, vid. infra la imagen de Jesús de la Sentencia.

42 LACHICA BENAVIDES, Fr. A. de: Gazetilla curiosa o Semanero granadino, noticioso y útil para el bien común. Granada, 1765, papel XXXVIII, hoja 2 v.

43 LÓPEZ MUÑOZ, M. L.: Contrarreforma y cofradías..., pág. 483 
José de Mora resulta evidente, aunque Gallego Burín no la contemplara en su monografía sobre el escultor bastetano 44 . Como en la primera de las imágenes relacionadas con Pedro de Mena, esta efigie - absorta en su dolor- parece derivar de los modelos de busto a que fueron tan aficionados ambos escultores. La prolongación en el resto del cuerpo alcanza un feliz resultado plástico. Su aparente frontalidad es dinamismo encubierto, cuyo ritmo marca la cabeza ligeramente inclinada hacia su derecha, la estructura diagonal del manto púrpura que desnuda un hombro en efectista y repetido recurso dramático, y la flexión de la pierna izquierda.

Llama la atención el intenso control de la composición y el modulado lenguaje gestual de la figura; la estudiada composición, habida cuenta el concepto frontal de la figura, bebe claramente de fuentes grabadas, desde el suave contraposto a la ligera inclinación de la cabeza, el cruce de manos o la ligereza del apoyo del pie izquierdo, lo que avala los conocimientos pictóricos del escultor bastetano. De hecho, se le atribuyen varios dibujos entre los cuales uno estudia esta iconografía 45 , lo que indica que la importancia del tema lo convierte en objeto de análisis y especulación. De este modo consigue un enorme efecto expresivo en una figura que, por plana, adquiere una cualidad cuasi gráfica, diríase que lineal, donde los pliegues de la túnica son efectos de claroscuro más que valoraciones de volumen. Pese a ese carácter "gráfico", con todo ello se anima una figura de magro y apurado modelado, muy en el tipo melancólico y lánguido, casi al borde del desmayo, de José de Mora. Subida calidad y belleza alcanza también el modelado en sus manos, cruzadas y atadas, que parecen querer recoger la caída del manto de tela encolada -nuevo recurso realista-, sobre todo en el pliegue entre el meñique y el anular de su mano izquierda, que fuerza así una composición en forma de sigma para esa mano, al modo de los retratos del Greco y como utiliza Cano en el Ángel Custodio de mármol para el convento granadino del mismo título, por ejemplo. Su delgadez y estilización incrementan el patetismo que comporta su policromía en tonos claros y en semibriIlo, que delata los rastros de la Pasión en su cuerpo. Su cabeza inclinada, con la mirada perdida, contrasta por su resignación con su dolorido cuerpo, inspirándole gran fuerza dramática 46 .

No es propiamente imagen procesional, pues no resiste los planos de perfil o trasero. Sin embargo, sí es imagen de alto contenido devoto, en la línea emocional y sublime de José de Mora ${ }^{47}$. Existe, además, una versión reducidísima de esta escultura, a

\footnotetext{
44 Más tarde (1936) la daría de José de Mora, pero citándola erróneamente como "una escultura del Señor atado a la columna", en Granada. Guía artística e histórica de la ciudad. Ed. de Granada, Comares, 1989 (1 ${ }^{a}$ ed. 1936-1944, pág. 352)

45 PÉREZ SÁNCHEZ, A. E.: "Miscelánea de dibujos granadinos", en Symposium internacional 'Alonso Cano y su época'". Granada, Consejería de Cultura, 2002, pág. 400.

46 BERNALES BALLESTEROS, J. y GARCÍA DE LA CONCHA DELGADO, F.: Imagineros andaluces de los siglos de oro. Sevilla, Editoriales Andaluzas Unidas, 1986, pág. 142.

47 Con esta autoría figuró en la exposición "Alonso Cano y su escuela", celebrada en Granada en 1968. Centenario de Alonso Cano..., pág. 91, nº 120.

48 Archivo de la Parroquia de San Pedro, "Circulares y oficios y otros documentos desde 1841 a 1845 ", leg.
} 


\section{1: artículos Juan Jesús López-Guadalupe Muñoz}

modo de tosco boceto en barro, en el convento de Santa Isabel la Real de Granada.

En cuanto a la procedencia de la imagen, tradicionalmente se consideraba procedente del cercano convento desamortizado de los mínimos. En el archivo parroquial queda constancia de su llegada al templo en 1844, cuando la Diputación Provincial dio orden de que se entregara al cura y beneficiados de esta parroquia "la efigie del Santo Cristo de la Humildad, que existe en el museo de pinturas (...) para darle el devido culto en uno de los altares de la capilla mayor"48. Sin duda, corresponde a una escultura que figura en un inventario de dicho museo - que recogía fondos procedentes de los conventos desamortizados-, fechado en 1842, con el número 847 , imagen "de estatura natural que representa un Ecce-Homo, con peana, su autor D. José de Mora"49, y que ya no aparece en los sucesivos inventarios.

Precisamente existe una imagen de estas características, de la que Gallego Burín no acertó a localizar su paradero. Se trata del Jesús de la Humildad del convento de Nuestra Señora del Carmen, de carmelitas calzados. El Padre Lachica ofrece la primera noticia sobre ella: "un hermoso simulacro de Jesús de la Paciencia y Humildad", muy milagroso, sobre todo en casos de sequía, citándola igualmente el Conde de Maule, en un altar colateral ${ }^{50}$. A comienzos del siglo XIX, los informadores granadinos de Ceán Bermúdez también dejaron constancia de ella: "en una capilla colateral a la maior, se venera una imagen de Jesús de la Humildad, del tamaño del natural, que ésta la dexó para una memoria a estos religiosos este grande artífice; siendo una estatua que manifiesta mui visiblemente los trabajos de su Pasión"51. La crónica de fray Miguel Rodríguez Carretero fecha la llegada de la misma al convento en $1685^{52}$ y un grabado dieciochesco permite identificarla con el Ecce-Homo que hoy se venera en la parroquia de San Pedro. Además constituye la única escultura del Ecce Homo de tamaño natural que se le conoce a Mora. En consecuencia, el actual Jesús de la Sentencia fue el antiguo de la Humildad del convento del Carmen, pasando tras la desamortización al Museo de Bellas Artes, en las dependencias de otro convento desamortizado, el de los dominicos de Santa Cruz la Real, siendo reclamado y entregado en 1844 a la parroquia de San Pedro con destino al culto. Justamente un siglo después, en 1944, se constituiría su actual hermandad, que completaría la escena de la Sentencia de Cristo con otras figuras.

Por otro lado, esta imagen también pudo ser la titular de una hermandad residente en el referido convento, la del Cristo de las Penas; aunque la cita Jorquera con

\footnotetext{
s.c., notificación de 17 de agosto de 1844.

49 Archivo de la Real Academia de Bellas Artes de San Fernando, "Copia del inventario de las pinturas y esculturas que existen en el Museo Provincial de Granada”, leg. 2-48/1 (cit. por VILLAFRANCA JIMÉNEZ, Ma M.: Los museos de Granada: génesis y evolución histórica. Granada: Diputación, 1998, pág. 366).

50 LACHICA BENAVIDES, Fr. A. de: Gazetilla..., papel XV, hoja 1 y 2 v; GALLEGO BURÍN, A.: José de Mora..., pág. 198.

51 SALAS, X. de: op. cit. pág. 38; CEÁN BERMÚDEZ, J. A.: Diccionario histórico de los más ilustres profesores de las Bellas Artes en España. Madrid, imprenta de la viuda de Ibarra, 1800, t. III, pág. 182.

52 RODRíguez CARRETERO, Fr. M.: "Epytome historial de los Carmelitas Calzados de Andalucía...", Biblioteca Nacional, Ms. 18.118, fol. 86.
} 
anterioridad a la realización de la imagen que aquí proponemos, ésta pudo ser renovada con el tiempo; la hermandad aún pervivía en 1804, según la relación de Rodríguez Carretero53.

Por último, cabe la consideración de un último Ecce Homo, esta vez de vestir, venerado en la parroquia de la Magdalena bajo la advocación de Jesús del Rescate [14]. Ha sido tradicionalmente atribuido al escultor bastetano José de Mora, en atención fundamentalmente a la compatibilidad estética entre su rostro y la tipología propia de este escultor, es decir, frente despejada, cejas enarcadas, nariz fina, mejillas huidizas y barba bífida. Su actual cabellera es obra de Navas Parejo realizada en cobre cincelado en 1929, pues poseía melena natural [15] de acuerdo con la iconografía a la que corresponde, la de Jesús de Medinaceli, que queda alterada con esta melena. De no restituirle — como se debiera - su primitivo aspecto, sí convendría al menos que poseyera una melena tallada que armonizara mejor con el resto de la imagen y con el estilo de este autor.

El notorio moratón en su mejilla izquierda es prácticamente el único signo de dolor en el rostro, casi limpio de sangre. Su belleza idealizada puede representar un punto de contacto con un imaginero intelectual como Mora, en una imagen mesurada que invita a la contemplación devota con un gesto sereno, impasible casi, y una mirada dulce y profunda 54 . Sus divinas manos están delicadamente trabajadas, con un modelado blando y naturalista, que deja los dedos sueltos, no agarrotados, siguiendo de cerca las manos del Jesús de la Sentencia.

Pese a todo hay un aire diferente en esta imagen con respecto a lo que consideramos obras seguras de José de Mora. Los referentes, lógicamente, son las versiones del Ecce-Homo, fundamentalmente en busto, que realizó este escultor. Las notas características e inspiradísimas de dolor y resignación también están presentes en el Jesús del Rescate, pero el tratamiento escultórico resulta diferente. El propio Gallego Burín en su monografía sobre José de Mora no lo menciona y, sin duda, lo conocía pues refiere en este libro los bustos de Ecce-Homo y Dolorosa que hoy se conservan en la iglesia de la Magdalena. Acabaría finalmente dando esta imagen como obra probable en su Guía de Granada (primera edición entre 1936 y 1944) en igualmente en una exposición celebrada en 1942 en la Casa de los Tiros. Pero cabe pensar en otro autor cercano.

Tradicionalmente se había considerado esta imagen como procedente del convento de la Santísima Trinidad, de trinitarios calzados. Sin embargo, un hallazgo documental nos permitió hace años precisar su exacta procedencia. Un inventario de bienes de la parroquia de la Magdalena, fechado en 1865, nos informa de lo siguiente: "Un altar, retablo antiguo en el que colocó la Parroquia la imagen de Ntra. Sra. de

53 HENRÍQUEZ DE JORQUERA, F.: op. cit., pág. 236; RODRÍGUEZ CARRETERO, Fr. M.: op. cit., fol. 85; LÓPEZ MUÑOZ, M. L.: Contrarreforma y cofradías..., pág. 492.

54 Presenta ojos de vidrio y pestañas naturales. La restauración realizada en 1997 por Bárbara Hasbach Lugo, eliminó una pieza postiza que tenía inserta en la cintura con la que se incrementaba su altura. 


\section{Q: artículos Juan Jesús López-Guadalupe Mñ̃oz}

Gracia, que pertenecía a los padres trinitarios descalzos. En dos repisas de los lados, Sta. Rita y Sta. Clara de Montefalco, y en la mesa de altar las imágenes de Jesús del Rescate y Ntra. Sra. de los Dolores, que eran también de los padres trinitarios descalzos, y en medio una urna de la parroquia para el sagrario, sobredorada". En un inventario posterior se ofrece una información adicional: "Ambas imágenes son de talla, vestidas: la imagen de Jesús con su túnica de terciopelo morado bordada, diadema de hojalata (la demás ropa la custodian las Madres), y la Virgen, vestido blanco de tul, manto negro de veludillo, media luna y corona de hojalata, y lo demás en las monjas" 55 .

Así pues, queda claro que esta imagen procedía del convento de Nuestra Señora de Gracia, de trinitarios descalzos. Por motivos que desconocemos -quizás por su enorme calado en la devoción popular- no retornó a esta iglesia como lo hizo la titular de aquel convento, la Virgen de Gracia, cuando su antiguo cenobio fue adquirido por el arzobispado en 1880 con destino a seminario.

Por otro lado, puede aseverarse que la advocación de esta imagen ha sido siempre la del Rescate, si bien procesionó entre 1925 y 1927 con el título de "Prendimiento de Jesús". También conocemos datos acerca de la veneración de esta imagen en el extinto convento trinitario. Allí existió la "Siempre Augusta y Venerable Hermandad de la Confraternidad de la Santísima Trinidad, Redempción de Cautivos", fundada en 1676, cuyo fin era ayudar a los cautivos cristianos en manos de los infieles. No poseía imagen titular propia, aunque veneraba un Cristo crucificado, bajo el título de la Redención, cuyo cuidado tenían encargado por la comunidad trinitaria56. Este Cristo, realizado en 1614, es el que actualmente se encuentra en el altar mayor de la parroquia de Gracia, a los pies de la Virgen de este título.

La imagen de Jesús del Rescate nació muy vinculada a dicha confraternidad. En 1718, la comunidad de frailes decidió encargar una imagen de Jesús, siguiendo la popular iconografía de Jesús de Medinaceli, extendida por esta orden. Éste es el testimonio que nos ofrece al respecto el ministro del convento de Gracia, fray Juan de San Calixto: "Teniendo hecha una imagen de Jesús Captibo, a similitud de otra que se rescató por nuestra Conmunidad de la pérdida de La Mamola (Mámora, en el Norte de África), i se halla colocada en el Real Combento de Madrid (Jesús de Medinaceli) i tractado de conducirla mañana biernes, que se contarán diez i ocho de el corriente - marzo- , desde el Combento de la Stma. Trinidad Calzados a el referido de Ntra. Sra. de Gracia para su colocación, Ilebando sólo la bandera de la Redempción, como insignia más propia de su función..."57. Así pues, la confraternidad concurrió a este traslado, el cual generó tensiones con el clero de la parroquia

55 Archivo de la Parroquia de la Magdalena, caja 46, Libro de Inventarios.

56 Archivo Histórico Nacional, Clero, libro 3862, págs. 14-15. La descripción del templo en NATIVIDAD, Fr. J. de la: Coronada historia... de... la milagrosa Imagen de María Santísima de Gracia, cuyo sagrado bulto y título glorioso ocupa y magnifica su real Templo y Convento de RR. PP. Trinitarios Descalzos... de Granada. Granada, impreso por Francisco de Ochoa, 1697, págs. 172-174. Sobre esta hermandad, vid. LÓPEZ MUÑOZ, M. L.: Contrarreforma y cofradías..., págs. 537-539.

57 Archivo Histórico del Arzobispado de Granada, leg. 37F, pza. 6 (Sobre la colocación de una imagen en el 
de la Magdalena por la percepción de derechos parroquiales ${ }^{58}$. Más tarde, en 1795 desapareció la confraternidad al fallecer el último de sus miembros, y en esta fecha fueron trasladados los restos de la bóveda de la confraternidad "a la bóveda nueva de la capilla principiada para Jesús del Rescate" 59 .

Una atenta lectura de las fuentes permite deducir que no se trató de un simple traslado entre conventos, sino de una procesión con motivo de la hechura de una imagen nueva, lo que justifica su presencia pública para ser admirada por los fieles durante el recorrido entre ambos conventos trinitarios, por otra parte bastante próximos. Así pues, podemos datar esta imagen en el año 1718, siguiendo muy de cerca, como ya se ha dicho, el modelo de Jesús de Medinaceli, venerado en Madrid, aunque obra andaluza del siglo XVII. El auge de esta devoción en los comienzos del Setecientos fue grande. En otras ciudades se realizaban por entonces imágenes similares; la cordobesa (Jesús Nazareno Rescatado, de la iglesia de Nuestra Señora de Gracia) había sido realizada en 1713 por el cordobés Fernando Díaz Pacheco. En torno a ambas imágenes, cordobesa y granadina, se generaron leyendas sobre su rescate en tierras de infieles.

La cronología de la granadina también nos introduce en la cuestión de su autoría. La fecha parece avanzada para un José de Mora que por entonces contaría ya setenta y seis años, y cuya última obra documentada, en la Cartuja, databa de seis años antes, lo que unido al pacífico desvarío en que cayó en sus últimos años dificulta un tanto la posible atribución. Por otra parte, aunque la adhesión a sus modelos es evidente, resulta una versión más dulcificada, de diferente técnica y sentimiento, lo que puede hacer pensar en un escultor muy cercano y poco conocido, su propio hermano Diego, que era dieciséis años menor que José y cuya última obra documentada es de 1726 (Virgen de las Mercedes, hoy en la parroquia de San Ildefonso $)^{60}$. Por tanto, la posibilidad real existe aunque el desconocimiento -aún mayor que en el caso de José- de la obra de Diego de Mora nos impide realizar una afirmación sin reservas. Por otra parte, en Diego no se agotan los seguidores del arte de José de Mora. Sobre sus patrones formales, el estilo de la imagen de Jesús del Rescate resulta compatible con la producción conocida de Agustín de Vera Moreno o de José Risueño. Al margen de la cuestión de la autoría, sin duda represen-

Convento de Nuestra Señora de Gracia, 1718), cit. por LÓPEZ MUÑOZ, M. L.: "La tradición trinitaria en Granada: Nuestro Padre Jesús del Rescate", Gólgota, 5, Granada, 1993, pág. 45.

58 Cfr. el documento citado en la nota anterior, trascrito íntegramente en GÓMEZ DÍAZ, J. M. y CÓRDOBA SALMERÓN, M.: Cofradía de Nuestro Padre Jesús del Rescate (LXXV aniversario). Granada, Comares, 2001, págs. 319-320.

59 LÓPEZ MUÑOZ, M. L.: "La tradición trinitaria en Granada...", pág. 46.

60 LÓPEZ-GUADALUPE MUÑOZ, J. J.: "Notas histórico-artísticas sobre la imagen de Nuestro Padre Jesús del Rescate", Christi Passio. Boletín de la Cofradía de Nuestro Padre Jesús del Rescate, 2, Granada, 1995 págs. 10-18. Corrobora esta atribución CÓRDOBA SALMERÓN, M.: Las órdenes religiosas y el arte barroco. El patrimonio de los trinitarios descalzos de Granada. Granada, Universidad, 2003, págs. 164-166 y "Un arte, una cofradía", en Cofradía de Nuestro Padre Jesús del Rescate..., págs. 288-289, quien especula incluso con la posibilidad de que sea una obra de colaboración entre José y Diego de Mora. 


\section{Q: artículos Juan Jesús López-Guadalupe Muñoz}
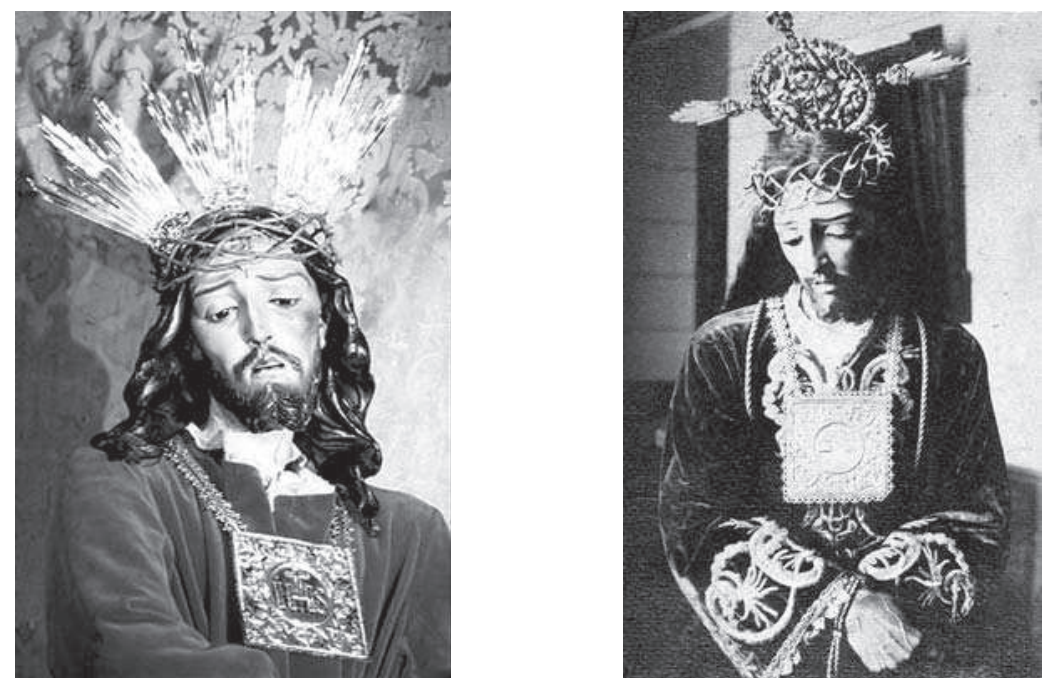

14. DIEGO DE MORA (?). Jesús del Rescate, 1718. Granada, iglesia de la Magdalena. 15. Jesús del Rescate con peluca natural, hacia 1925.

ta una imagen de alta significación espiritual en el panorama devocional granadino, en la línea del Cristo de Medinaceli, vestigio de la primitiva presencia de los trinitarios en Granada, acertadamente recuperada en su advocación por su actual hermandad.

\section{Conclusión.}

Queda bien de manifiesto la importancia histórica y devocional que el tema del Ecce Homo posee en el arte y en la religiosidad de la Granada moderna, extendiendo su eficacia hasta nuestros días de la mano de las imágenes procesionales, reforzadas con modernas realizaciones. Florecen sus contenidos simbólicos en el paso entre el hecho narrativo evangélico (o apócrifo, en ocasiones) y su representación figurada, conformando de esta manera un rico venero visual y espiritual, del que se nutren el imaginario colectivo (mental y artístico) y la ejemplaridad moral de la modernidad.

Las experiencias plásticas que este proceso genera conducen a destacar la esencial cualidad granadina de las imágenes de oratorio e incluso de alcoba, de consumo privado, pero también a la revalorización de las imágenes procesionales, que desde rígidos supuestos la crítica suele relegar en el caso granadino y que en el tema del Ecce Homo también existen. Ciertamente, la excepcional abundancia de 


\section{artículos Entre la narración y el símbolo: Iconografia del Ecce Homo...}

realizaciones de busto de este tema no se corresponde con la serie mucho más corta de las figuras completas del mismo. Aunque la frecuencia iconográfica en figura completa sea menor que en tipos como el Nazareno o el Crucificado, la iconografía del Ecce-Homo estuvo permanentemente presente en la escultura procesional de la Semana Santa granadina, resultando un hito imprescindible en el relato visual de la Pasión de Cristo que las prácticas procesionales proponen. A partir de ahí, esta ausencia iconográfica de las figuras completas se vería compensada por la extraordinaria abundancia de las figuras de busto en pequeño y mediano formato.

Por otro lado, conviene tener en cuenta que el carácter individual y aislado de la imagen barroca granadina de devoción afectó también a la escultura procesional, reduciendo los protagonistas de sus "pasos" a la sola imagen de Cristo o de la Virgen, salvo en casos en que la composición es forzosa, como ocurre con la Piedad o Virgen de las Angustias. Aun así, los cortejos procesionales se veían, como en tantos otros lugares, animados por las representaciones vivientes, como en la actualidad mantiene una de las cofradías granadinas. Pero siempre el núcleo aglutinador ha sido la imagen. El ramillete de ejemplos que aquí se muestra, de calidad diversa, refleja la demanda devocional a la que responden estas imágenes, el gran auge de la meditación de la Pasión de Cristo durante la modernidad y su eficacia ritual y espiritual, en actividades cultuales, procesionales o de simple oración individual. Queda demostrado, también, que una comprensión certera y ajustada de la importancia y valores de este tema requiere necesariamente subrayar su alto valor simbólico, más que narrativo, lo que entiendo que condicionó no sólo su desarrollo iconográfico sino también su uso devocional con una inmediata repercusión en su formato. 
